Estudios Constitucionales, Año 9, No 1, 2011, pp. 119 - 156.

ISSN 0718-0195

Centro de Estudios Constitucionales de Chile Universidad de Talca

"El uso del postulado de proporcionalidad en la jurisprudencia de la Corte Interamericana de Derechos Humanos sobre libertad de expresión”

Humberto Nogueira Alcalá

\title{
EL USO DEL POSTULADO DE PROPORCIONALIDAD EN LA JURISPRUDENCIA DE LA CORTE INTERAMERICANA DE DERECHOS HUMANOS SOBRE LIBERTAD DE EXPRESIÓN.
}

\author{
USING THE ASSUMPTION OF PROPORTIONALITY IN THE \\ JURISPRUDENCE OF THE INTER-AMERICAN COURT OF HUMAN \\ RIGHTS ON FREEDOM OF EXPRESSION
}

Humberto Nogueira Alcala ${ }^{1}$

Profesor Titular de Derecho Constitucional, Universidad de Talca

nogueira@utalca.cl

Resumen: El artículo analiza los enfoques de la Corte Interamericana de Derechos Humanos en materia de libertad de expresión, donde utiliza la perspectiva de la delimitación del derecho, determinando su contenido básico o esencial y sus límites, como ocurre en el caso "La última tentación de Cristo", o buscando la concordancia práctica del sistema de derechos utiliza el principio de proporcionalidad en sentido formal y el sistema de pesos en su jurisprudencia más reciente.

AвSTRACT: The article examines the approaches of the Interamerican Court of Human Rights on freedom of expression, which uses the perspective of defining the right to determine its basic or essential content and his limits, as in the case The Last Temptation of Christ, or looking for practical concordance rights system uses the principle of proportionality in the formal sense, and the system of checks in his latest case law.

Palabras Clave: Postulado de proporcionalidad; Jurisprudencia de libertad de expresión; Corte Interamericana de Derechos Humanos.

KEYWORDS: Postulate of proportionality; jurisprudence of freedom of expression; Inter American Court of Human Rights.

\section{INTRODUCCIÓN.}

El postulado de proporcionalidad tiene su origen en el derecho administrativo alemán donde se utiliza para controlar los poderes discrecionales de la adminis-

${ }^{1}$ El autor es Doctor en Derecho por la Universidad Católica de Lovaina La Nueva, Bélgica. Director del Centro de Estudios Constitucionales de Chile y del Magíster en Derecho Constitucional y Derechos Humanos. Vicepresidente del Instituto Iberoamericano de Derecho Procesal Constitucional. Presidente de la Asociación Chilena de Derecho Constitucional. Miembro de la Academia Internacional de Derecho Comparado de La Haya. Este artículo constituye una versión revisada del texto presentado en el proyecto de Investigación: El diálogo entre los sistemas americano y europeo de derechos: SEMINARIO INTERNACIONAL DE ALTA ESPECIALIZACIÓN: EL DIÁLOGO ENTRE LOS SISTEMAS AMERICANO Y EUROPEO DE PROTECCIÓN DE DERECHOS HUMANOS, Sevilla, 21-10-2010. nogueira@ utalca.cl Presentado con fecha 7 de diciembre de 2010 y aprobado con fecha 11 de mayo de 2011. 
tración, de allí fue tomado por la jurisprudencia de la Corte Constitucional de Karlsruhe, convirtiéndolo en un elemento inherente al Estado de Derecho y la justicia, elevándolo al rango de principio o postulado constitucional, constituyéndolo en un parámetro de control de constitucionalidad de la actuación de los poderes estatales, luego se ha difundido a las jurisdicciones internacionales de derechos humanos, en especial en Europa, en la materia es bastante conocida la jurisprudencia del Tribunal Europeo de Derechos Humanos a partir del caso Handyside $^{2}$, como asimismo del Tribunal de Justicia de la Unión Europea, a partir del caso Internationale Handelgesellschaft ${ }^{3}$, donde el principio de proporcionalidad es un parámetro de control para analizar la legitimidad de cualquier restricción normativa de los derechos fundamentales ${ }^{4}$.

En el presente artículo se realizará un análisis del uso por la Corte Interamericana de Derechos Humanos de dicho principio o postulado de proporcionalidad en su aplicación a la consideración del derecho a la libertad de expresión, cuando ésta entra en tensión con otros derechos o bienes jurídicos contenidos en la Convención Americana.

\section{El PRINCIPIO DE PROPORCIONALIDAD O PRINCIPIO DE PROHIBICIÓN DE EXCESO.}

El principio de proporcionalidad constituye una técnica aplicable especialmente a la intervención del Estado legislador en el ámbito de los derechos fundamentales. Constituye un parámetro de control cada vez que con objeto de optimizar un bien colectivo, el legislador limita o restringe un derecho fundamental.

El principio o postulado de proporcionalidad instituye una relación de fin a medio, como asimismo de utilidad de un acto, confrontando el fin de una intervención con los efectos de ésta, posibilitando un control de exceso, protegiendo a las personas respecto de los abusos o arbitrariedades del poder estatal, sin perjuicio de constituir un principio de interpretación en que se apoya el operador jurídico, en especial el juez, cuando necesita resolver problemas de compatibilidad o de conformidad en la tarea de concretización de las normas constitucionales en relación con las normas legales y administrativas 5 .

El principio de proporcionalidad se descompone en tres subprincipios: el de adecuación o idoneidad de los medios; el de necesidad y el de proporcionalidad en

\footnotetext{
${ }^{2}$ TEDH. Sentencia de fecha 16 de diciembre de 1976.

${ }^{3}$ TEDH. Sentencia de 17 de diciembre de 1970, asunto 11/70, Rep. 70, 1125.

${ }^{4}$ FAssbender, Bardo. (1998), pp. 51-74

${ }^{5}$ Ver Bernal Pulido, Carlos. (2003). pp. 97 y ss.
} 
sentido estricto. Los tres operan copulativamente, no basta cumplir con algunos de ellos, todos deben ser asumidos para que el precepto normativo se considere legítimo, justo y adecuado ${ }^{6}$.

a) El principio o examen de adecuación o conformidad de los medios a los fines.

Los derechos fundamentales o humanos en cuanto contenido central del ordenamiento contenidos en la $\mathrm{CADH}$, sólo pueden ser limitados en virtud de un bien protegido o de relevancia convencional, no pudiendo ser limitados por bienes o intereses de menor relevancia jurídica. La norma jurídica estatal examinada podrá perseguir uno o más fines convencionales legítimos, excluyendo cualquier medio que no sea conducente a un fin legítimo perseguido.

La finalidad debe ser lo más concreta posible no pudiendo justificarse en bienes indeterminados o de dudoso anclaje convencional.

Así cualquier norma jurídica restrictiva del derecho a la libertad de expresión debe ser idónea a la finalidad compatible con la $\mathrm{CADH}$ que se busca concretar, si la norma contraviene fines o valores expresos o implícitos en el texto convencional, será considerada contraria a la CADH e ilegitima, constituyendo una vulneración del derecho a la libertad de expresión, además de vulnerar las obligaciones generales de respeto y garantía del derecho contenidos en el artículo $1^{\circ}$ y el deber convencional de adecuar el ordenamiento estatal a través de medidas legislativas o de otro carácter, entre las cuales se encuentran las resoluciones judiciales, los actos de la administración o de cualquier otro órgano estatal, de acuerdo a lo que prescribe el artículo $2^{\circ}$ de la CADH.

\section{b) El principio o examen de necesidad o de intervención minima.}

De acuerdo a este subprincipio debe analizarse si la norma restrictiva del derecho a la libertad de expresión es una medida indispensable, no existiendo otra medida alternativa a la considerada que sea igualmente efectiva para lograr la finalidad convencionalmente legítima y sea menos restrictiva del o de los derechos afectados.

El subprincipio de necesidad exige que la medida restrictiva sea indispensable para la conservación de un derecho o de un bien jurídico convencional y no sea posible de ser substituida por otra medida igualmente eficaz pero menos gravosa. En el fondo se exige que la norma jurídica o actuación emanada del Estado sea imprescindible para asegurar la vigencia o ejercicio de un derecho o bien jurídico legítimo convencional, debiendo restringir otro en el menor grado posible cuando no existe otra alternativa posible, escogiendo siempre el mal

${ }^{6}$ Sobre la materia ver Alexy, R. (1993). Bernal Pulido, Carlos (2003). Cianciardo, J. (2004). Lopera Mesa, G. (2006). Carbonell, Miguel (Coord.) (2010). 
menor, el medio menos restrictivo, todo ello sin afectar el contenido esencial de los derechos afectados.

En este ámbito se establecen estándares más rigurosos para su operacionalidad práctica, ellos son:

i) una necesidad material, el medio debe ser el que afecte menos los derechos humanos.

ii) La exigibilidad espacial, el medio debe ser aquel que establezca el menor ámbito de limitación de los derechos afectados;

iii) La exigibilidad temporal, supone la delimitación más rigurosa del tiempo de aplicación de la medida que afecta los derechos;

iv) La exigibilidad personal, debe limitarse en la medida de lo posible las personas que sean afectadas en sus derechos.

El juez o corte debe considerar que entre más sensible sea el perjuicio que se cause al ejercicio de un derecho fundamental, más fuertes deberán ser los intereses de la comunidad que determinan la restricción normativa del ejercicio de uno o más derechos. Un medio es adecuado cuando el Estado o sus órganos no hubieren podido elegir otra medida igualmente efectiva, que hubiere restringido menos el derecho afectado.

En el ámbito de la tarea jurisdiccional, el tribunal o corte puede encontrarse con la existencia de diversos enunciados normativos de carácter jurídico normativo, donde unos tengan una dimensión menos restrictiva de los derechos fundamentales que otras, en la medida que ellas sean convencionales, el órgano jurisdiccional sólo podrá basar su decisión jurisdiccional en aquella medida que siendo igualmente eficaz, sea menos gravosa para el o los derechos de la persona afectada.

c) El sub principio de proporcionalidad en sentido estricto.

Este examen de proporcionalidad en sentido estricto examina si la limitación o restricción producida al o a los derechos constituye una medida equilibrada y justa entre el beneficio para el bien común que se obtiene de la limitación y el perjuicio que sufre el derecho afectado. Se trata de un análisis ponderativo, se ponen en la balanza, las ventajas e inconvenientes que se producirían para aquellos afectados en el ejercicio de sus derechos y para el bien público. Cuanto más grave o pesada sea la intervención los derechos fundamentales de las personas afectadas, debe existir una más intensa afectación del interés público que la justifique. El beneficio obtenido con la intervención del o de los derechos debe ser proporcional a la carga impuesta a ellos, debiendo existir una justa medida, impidiendo medidas desproporcionadas que afecten los derechos.

En el juicio de proporcionalidad en sentido estricto, el discernimiento debe realizarse identificando, en primer lugar, los valores, principios y derechos conven- 
cionales que se presentan en eventual conflicto o tensión; luego, en segundo lugar, atribuyendo una valoración específica a cada uno de los derechos fundamentales y bienes en conflicto, considerando las circunstancias del caso, argumentando sobre el grado de cumplimiento del principio y el grado de compromiso o perjuicio para el derecho o bien constitucional contrario para cada una de las eventuales soluciones del conflicto; en tercer y último lugar, se adopta la decisión de prevalencia de acuerdo con el criterio de que "cuanto mayor sea el grado de perjuicio a uno de los principios o derechos mayor debe ser la importancia del cumplimiento de su contrario" 7 .

Este subprincipio implica ponderar, en una relación costo beneficio, las ventajas o desventajas resultantes para las personas de los medios utilizados por el legislador para obtener los fines perseguidos por la norma constitucional. Se ponderan los daños que se causan con la adopción de la medida versus los resultados positivos que serán alcanzados por la dictación de la medida o norma para el bien común. Esto implica un juicio ponderativo, vale decir, un medio o método a través del cual se desarrolla el juicio que se realiza en cada caso concreto, teniendo por tanto, una aplicación casuística.

La gradación del escrutinio del principio de proporcionalidad obliga así a un análisis de la legitimidad del objetivo convencional que persigue la norma o medida estatal, la idoneidad de la medida que establece la diferenciación para alcanzar la finalidad compatible con la Convención, la consideración que tal objetivo podría ser alcanzado por un medio igualmente idóneo o más idóneo que no implicara la diferenciación (principio de necesidad), como asimismo, que la legitimidad de las diferenciaciones depende de la relación existente entre la intensidad en que se alcanza el objetivo de la medida y las intensidades que se afecta el o los derechos fundamentales afectados.

Finalmente, es necesario precisar que el principio de proporcionalidad opera con la técnica de la aplicación escalonada. Ello implica que, en primer lugar, debe examinarse si una medida persigue un fin constitucionalmente legítimo, sólo cuando ello ocurre se analizará si dicha medida constituye un medio adecuado para obtener el fin perseguido. Si la medida no persigue un fin constitucionalmente legítimo no es necesario seguir el análisis, ya que la medida por ese solo hecho es inconstitucional. En el caso de que el fin sea legítimo, se analiza si la medida adoptada es adecuada y necesaria para lograr el fin constitucionalmente legítimo, sólo si se considera que dicha medida lo es, se pasará al tercer escalón de análisis, si la medida no es adecuada al fin constitucional se concluye el análisis y se determina la inconstitucionalidad de ella. Sólo si la medida es considerada adecuada a la

${ }^{7}$ Brage Camazano, Joaquín. (2004). p. 383. 
obtención del fin constitucionalmente legítimo se pasa al tercer escalón de análisis, evaluando si dicha medida es la que menos daña el ejercicio de los derechos en vista del objetivo perseguido, estableciendo una adecuada proporcionalidad entre beneficio y daño. Si existen otras medidas alternativas que permitan alcanzar el mismo objetivo con menor intensidad de restricción de derechos, en tal caso la medida será inconstitucional.

Es necesario especificar que el principio de proporcionalidad suele aplicarse con diferentes intensidades, materia que en la doctrina alemana ha tratado R. Alexy ${ }^{8}$, que debe tener en consideración "la seguridad que ofrezcan las premisas empíricas analíticas y normativas relevantes, y de acuerdo con la intensidad de la injerencia de los poderes públicos en el derecho fundamental objeto de consideración' ${ }^{9}$ Esta perspectiva ha sido desarrollada y precisada, entre otros autores, por Laura Clérico ${ }^{10}$.

En tal perspectiva, puede sostenerse que mientras sea mayor o más intensa la injerencia en el derecho fundamental y más seguras sean las premisas relevantes, debe ser más estricto el escrutinio en base al principio de proporcionalidad.

3. El postulado de proporcionalidad en la jurisprudencia de la Corte Interamericana de Derechos Humanos en materia de libertad de EXPresión.

\subsection{Algunas consideraciones básicas preliminares.}

En la teoría de las normas, se distingue entre reglas y principios.

Una norma está expresada como regla cuando, dado un antecedente, se deduce necesariamente una consecuencia, siendo su forma de aplicación la subsunción, por ejemplo, la regla que prohíbe la desaparición forzada de personas o la que prohíbe la tortura o los tratos crueles, inhumanos o degradantes, en tales casos la regla es perentoria e inderogable, no hay otro principio que pueda oponerse al cumplimiento de la regla, no valen ni la guerra ni los estados de excepción ni la lucha contra el terrorismo.

Las normas de principio son aquellas que se diferencian de las primeras porque exigen que algo sea desarrollado y cumplido en la mayor medida posible, por lo que no opera la subsunción, siendo ejemplo, la concreción de la libertad de expresión; el respeto de la honra de las personas, donde los principios deben ser ponderados, pudiendo utilizarse la regla, postulado o principio de proporcionalidad.

\footnotetext{
${ }^{8}$ Alexy, R. "Epílogo a la Teoría de los derechos fundamentales", Revista Española de Derecho Constitucional $N^{\circ}$ 66, Madrid, Ed. Centro de Estudios Constitucionales.

${ }^{9}$ Bernal Pulido, Carlos (2005), p. 265.

${ }^{10}$ Clérico, Laura (2009).
} 
En el ámbito de las normas de derechos humanos nos encontramos con reglas y con principios, en el primer caso sólo cabe la subsunción, en el caso de los principios opera la ponderación y el postulado de proporcionalidad.

Como señala Laura Clérico en un estudio efectuado sobre la jurisprudencia de la Corte interamericana de Derechos Humanos, sobre un universo de 274 casos contenciosos, 20 opiniones consultivas y 403 medidas provisionales, sólo un 10\% de los casos contenciosos aplicó el principio de proporcionalidad $\left.{ }^{11}\right)$.

En materia de libertad de opinión e información, la Corte Interamericana ha aplicado el postulado de proporcionalidad en diversas etapas de su jurisprudencia, para determinar la legitimidad o no de su restricción o limitación en virtud de otros derechos o de bienes jurídicos contenidos en la CADH.

En tal perspectiva, desarrollaremos la utilización de dicho principio de proporcionalidad por la jurisprudencia de la Corte Interamericana de Derechos Humanos en casos específicos y distintas etapas del desarrollo jurisprudencial de la Corte.

En una primera etapa de la jurisprudencia de la Corte Interamericana, en la Opinión Consultiva No 5, se aplican los subprincipios básicos del principio de proporcionalidad en la perspectiva desarrollada por la dogmática alemana, para determinar la restricción del derecho a la libertad de expresión del artículo 13 de la CADH mediante la Colegiación Obligatoria de Periodistas.

En una segunda etapa, ya en casos contenciosos, como es el caso de la "Última Tentación de Cristo" vs. Chile, donde se plantea la censura judicial de la película en virtud del honor de Cristo, el tema se resuelve no por ponderación sino por subsunción, en la medida que el artículo 13 de la CADH determina la regla de prohibición de censura previa y sólo posibilita responsabilidades ulteriores, donde hay una diferencia específica de tipo normativo con el sistema europeo de derechos humanos, el cual no contiene en el texto de la Convención la prohibición expresa de censura previa.

En una tercera etapa, la Corte utiliza la ponderación y el principio de proporcionalidad para los casos de conflictos del derecho a la libertad de expresión y el derecho a la honra (Caso Kimel vs. Argentina y caso Usón vs. Venezuela), en que se utiliza el principio de proporcionalidad a través del criterio del peso de los bienes jurídicos o derechos en juego, de acuerdo a reglas, donde destacan las siguientes: i) el grado de afectación de uno de los bienes en juego, determinando si la intensidad de dicha afectación fue grave, intermedia o moderada; ii) la importancia de la satisfacción del bien contrario, y iii) si la satisfacción de éste justifica la restricción del otro.

${ }^{11}$ Clérico, Laura (2010). 


\subsection{Libertad de información y utilización del postulado de proporcionalidad en la Opinión Consultiva No 5.}

En la Opinión Consultiva No 5, la Corte Interamericana analiza si la colegiación obligatoria de periodistas es compatible con la libertad de expresión del artículo 13 de la Convención:

La Corte Interamericana parte precisando el alcance la Libertad de expresión en la CADH:

"30. El artículo 13 señala que la libertad de pensamiento y expresión "comprende la libertad de buscar, recibir y difundir informaciones e ideas de toda indole...". Esos términos establecen literalmente que quienes están bajo la protección de la Convención tienen no sólo el derecho y la libertad de expresar su propio pensamiento, sino también el derecho y la libertad de buscar, recibir y difundir informaciones e ideas de toda indole. Por tanto, cuando se restringe ilegalmente la libertad de expresión de un individuo, no sólo es el derecho de ese individuo el que está siendo violado, sino también el derecho de todos a "recibir" informaciones e ideas, de donde resulta que el derecho protegido por el artículo 13 tiene un alcance y un carácter especiales.

31. En su dimensión individual, la libertad de expresión no se agota en el reconocimiento teórico del derecho a hablar o escribir, sino que comprende además, inseparablemente, el derecho a utilizar cualquier medio apropiado para difundir el pensamiento y hacerlo llegar al mayor número de destinatarios. Cuando la Convención proclama que la libertad de pensamiento y expresión comprende el derecho de difundir informaciones e ideas "por cualquier... procedimiento", está subrayando que la expresión y la difusión del pensamiento $y$ de la información son indivisibles, de modo que una restricción de las posibilidades de divulgación representa directamente, y en la misma medida, un límite al derecho de expresarse libremente. De alli la importancia del régimen legal aplicable a la prensa y al status de quienes se dediquen profesionalmente a ella.

32. En su dimensión social, la libertad de expresión es un medio para el intercambio de ideas e informaciones y para la comunicación masiva entre los seres humanos. Así como comprende el derecho de cada uno a tratar de comunicar a los otros sus propios puntos de vista implica también el derecho de todos a conocer opiniones y noticias. Para el ciudadano común tiene tanta importancia el conocimiento de la opinión ajena o de la información de que disponen otros como el derecho a difundir la propia.

33. Las dos dimensiones mencionadas de la libertad de expresión deben ser garantizadas simultáneamente.

34. Así, si en principio la libertad de expresión requiere que los medios de comunicación social estén virtualmente abiertos a todos sin discriminación, o, más exactamente, que no haya individuos o grupos que, a priori, estén excluidos del acceso a tales medios, exige igualmente ciertas condiciones respecto de éstos, de manera que, en la práctica, sean verdaderos instrumentos de esa libertad y no vehiculos para restringirla. Son los medios de comunicación social los que sirven para materializar el ejercicio de la libertad de expresión, 
de tal modo que sus condiciones de funcionamiento deben adecuarse a los requerimientos de esa libertad. Para ello es indispensable, inter alia, la pluralidad de medios, la prohibición de todo monopolio respecto de ellos, cualquiera sea la forma que pretenda adoptar, y la garantia de protección a la libertad e independencia de los periodistas.

35. Lo anterior no significa que toda restricción a los medios de comunicación o, en general, a la libertad de expresarse, sea necesariamente contraria a la Convención, cuyo artículo 13.2 dispone:

Artículo 13.2.- El ejercicio del derecho previsto en el inciso precendente no puede estar sujeto a previa censura sino a responsabilidades ulteriores, las que deben estar expresamente fijadas por la ley y ser necesarias para asegurar:

a) el respeto a los derechos o a la reputación de los demáso

b) la protección de la seguridad nacional, el orden público o la salud o la moral públicas.

En tal perspectiva, la Corte Interamericana analiza si los fines de la colegiación obligatoria están dentro de aquellos que se encuentran autorizados convencionalmente:

"59. La cuestión que se plantea entonces es si los fines que se persiguen con tal colegiación entran dentro de los autorizados por la Convención, es decir, son "necesari(os) para asegurar: a) el respeto a los derechos o a la reputación de los demás, o b) la protección de la seguridad nacional, el orden público o la salud o la moral públicas" (art. 13.2).

En abono de la legitimidad de la colegiación obligatoria se esgrime que la colegiación obligatoria perseguía fines de utilidad colectiva como la ética y la responsabilidad profesionales:

"61. En segundo lugar se ha sostenido que la colegiación obligatoria persigue fines de utilidad colectiva vinculados con la ética y la responsabilidad profesionales. El Gobierno mencionó una decisión de la Corte Suprema de Justicia de Costa Rica en cuyos términos es verdad que esos colegios también actúan en interés común y en defensa de sus miembros, pero nótese que aparte de ese interés hay otro de mayor jerarquía que justifica establecer la colegiatura obligatoria en algunas profesiones, las que generalmente se denominan liberales, puesto que además del título que asegura una preparación adecuada, también se exige la estricta observancia de normas de ética profesional, tanto por la indole de la actividad que realizan estos profesionales, como por la confianza que en ellos depositan las personas que requieren de sus servicios. Todo ello es de interés público y el Estado delega en los colegios la potestad de vigilar el correcto ejercicio de la profesión.

Dentro de la misma orientación, un delegado de la Comisión, en la audiencia pública de 8 de noviembre de 1985, concluyó que 
la colegiatura obligatoria para periodistas o la exigencia de tarjeta profesional no implica negar el derecho a la libertad de pensamiento y expresión, ni restringirla o limitarla, sino únicamente reglamentar su ejercicio para que cumpla su función social, se respeten los derechos de los demás y se proteja el orden público, la salud, la moral y la seguridad nacionales. La colegiatura obligatoria busca el control, la inspección y vigilancia sobre la profesión de periodistas para garantizar la ética, la idoneidad y el mejoramiento social de los periodistas.

En el mismo sentido, el Colegio de Periodistas afirmó que "la sociedad tiene derecho, en aras de la protección del bien común, de regular el ejercicio profesional del periodismo"; e igualmente que "l manejo de este pensamiento ajeno, en su presentación al público requiere del trabajo profesional no solamente capacitado, sino obligado en su responsabilidad y ética profesionales con la sociedad, lo cual tutela el Colegio de Periodistas de Costa Rica".

La Corte Interamericana considera que la Colegiación Obligatoria tiende a justificarse como un medio para asegurar el orden público o como una justa exigencia del bien común en una sociedad democrática:

"63. La Corte, al relacionar los argumentos asi expuestos con las restricciones a que se refiere el articulo 13.2 de la Convención, observa que los mismos no envuelven directamente la idea de justificar la colegiación obligatoria de los periodistas como un medio para garantizar "el respeto a los derechos o a la reputación de los demás" o "la protección de la seguridad nacional, "o la salud o la moral públicas" (art. 13.2); más bien apuntarían a justificar la colegiación obligatoria como un medio para asegurar el orden público (art. 13.2.b)) como una justa exigencia del bien común en una sociedad democrática (art. 32.2).”

La Corte Interamericana precisa el sentido y alcance del concepto de orden público en el ámbito convencional:

"64. En efecto, una acepción posible del orden público dentro del marco de la Convención, hace referencia a las condiciones que aseguran el funcionamiento armónico y normal de las instituciones sobre la base de un sistema coherente de valores y principios. En tal sentido podrian justificarse restricciones al ejercicio de ciertos derechos y libertades para asegurar el orden público. La Corte interpreta que el alegato según el cual la colegiación obligatoria es estructuralmente el modo de organizar el ejercicio de las profesiones en general y que ello justifica que se someta a dicho régimen también a los periodistas, implica la idea de que tal colegiación se basa en el orden público."

La Corte Interamericana precisa también el alcance del concepto de bien común:

65. El bien común ha sido directamente invocado como uno de los justificativos de la colegiación obligatoria de los periodistas, con base en el artículo 32.2 de la Convención. 
66. Es posible entender el bien común, dentro del contexto de la Convención, como un concepto referente a las condiciones de la vida social que permiten a los integrantes de la sociedad alcanzar el mayor grado de desarrollo personal y la mayor vigencia de los valores democráticos. En tal sentido, puede considerarse como un imperativo del bien común la organización de la vida social en forma que se fortalezca el funcionamiento de las instituciones democráticas y se preserve y promueva la plena realización de los derechos de la persona humana. De ahi que los alegatos que situan la colegiación obligatoria como un medio para asegurar la responsabilidad y la ética profesionales y, además, como una garantía de la libertad e independencia de los periodistas frente a sus patronos, deben considerarse fundamentados en la idea de que dicha colegiación representa una exigencia del bien común.

La Corte Interamericana determina que los bienes jurídicos aludidos y considerados no pueden suprimir un derecho humano ni privarlo de contenido, asumiendo la perspectiva de un contenido esencial o mínimo de cada derecho:

67. (...)A este respecto debe subrayarse que de ninguna manera podrian invocarse el "orden público" o el "bien común" como medios para suprimir un derecho garantizado por la Convención o para desnaturalizarlo o privarlo de contenido real (ver el art. 29.a) de la Convención). Esos conceptos, en cuanto se invoquen como fundamento de limitaciones a los derechos humanos, deben ser objeto de una interpretación estrictamente ceñida a las "justas exigencias" de "una sociedad democrática" que tenga en cuenta el equilibrio entre los distintos intereses en juego y la necesidad de preservar el objeto y fin de la Convención.

Luego la Corte Interamericana analiza la coherencia de la utilización de la colegiación obligatoria de periodistas con el fin de mantener el orden público:

68. La Corte observa que la organización de las profesiones en general, en colegios profesionales, no es per se contraria a la Convención sino que constituye un medio de regulación $y$ de control de la fe pública y de la ética a través de la actuación de los colegas. Por ello, si se considera la noción de orden público en el sentido referido anteriormente, es decir, como las condiciones que aseguran el funcionamiento armónico y normal de las instituciones sobre la base de un sistema coherente de valores y principios, es posible concluir que la organización del ejercicio de las profesiones está implicada en ese orden.

Sin embargo, la Corte precisa que la libertad de expresión es parte esencial del orden público primario de la sociedad democrática, donde ella juega una función determinante en su mantenimiento y adecuado funcionamiento:

69. Considera la Corte, sin embargo, que el mismo concepto de orden público reclama que, dentro de una sociedad democrática, se garanticen las mayores posibilidades de circulación de noticias, ideas y opiniones, asi como el más amplio acceso a la información por parte de la sociedad en su conjunto. La libertad de expresión se inserta en el orden 
público primario y radical de la democracia, que no es concebible sin el debate libre y sin que la disidencia tenga pleno derecho de manifestarse.

70. La libertad de expresión es una piedra angular en la existencia misma de una sociedad democrática. Es indispensable para la formación de la opinión pública. Es también conditio sine qua non para que los partidos politicos, los sindicatos, las sociedades cientificas y culturales, y en general, quienes deseen influir sobre la colectividad puedan desarrollarse plenamente. Es, en fin, condición para que la comunidad, a la hora de ejercer sus opciones, esté suficientemente informada. Por ende, es posible afirmar que una sociedad que no está bien informada no es plenamente libre.

La Corte Interamericana destaca la particularidad de la actividad periodística y su vinculación esencial con el ejercicio de la libertad de expresión:

71. Dentro de este contexto el periodismo es la manifestación primaria y principal de la libertad de expresión del pensamiento y, por esa razón, no puede concebirse meramente como la prestación de un servicio al público a través de la aplicación de unos conocimientos o capacitación adquiridos en una universidad o por quienes están inscritos en un determinado colegio profesional, como podría suceder con otras profesiones, pues está vinculado con la libertad de expresión que es inherente a todo ser humano.

72. (...) El problema surge del hecho de que el articulo 13 expresamente protege la libertad de "buscar, recibir y difundir informaciones e ideas de toda indole... ya sea oralmente, por escrito o en forma impresa...". La profesión de periodista-lo que hacen los periodistas-implica precisamente el buscar, recibir y difundir información. El ejercicio del periodismo, por tanto, requiere que una persona se involucre en actividades que están definidas o encerradas en la libertad de expresión garantizada en la Convención.

74. (...) El ejercicio del periodismo profesional no puede ser diferenciado de la libertad de expresión, por el contrario, ambas cosas están evidentemente imbricadas, pues el periodista profesional no es, ni puede ser, otra cosa que una persona que ha decidido ejercer la libertad de expresión de modo continuo, estable y remunerado.

La Corte considera al final de su análisis que el fin invocado para la colegiación obligatoria de periodistas no es válido para limitar la libertad de expresión de quienes ejercen el periodismo sin estar colegiados, estableciendo una limitación permanente a la libertad de expresión contenida en el art. 13 de la CADH:

76. La Corte concluye, en consecuencia, que las razones de orden público que son válidas para justificar la colegiación obligatoria de otras profesiones no pueden invocarse en el caso del periodismo, pues conducen a limitar de modo permanente, en perjuicio de los no colegiados, el derecho de hacer uso pleno de las facultades que reconoce a todo ser humano el artículo 13 de la Convención, lo cual infringe principios primarios del orden público democrático sobre el que ella misma se fundamenta. 
La Corte señala que no basta que el medio colegiación obligatoria de periodistas sea conducente a un objetivo legítimo, proteger a los periodistas, garantizando su libertad e independencia, sino que además debe analizarse si la restricción que ello significa para el ejercicio del derecho a la libertad de expresión. Ello implica evaluar si el medio utilizado por el Estado Parte es imprescindible, vale decir, si el objetivo perseguido no pueda alcanzarse a través de otro medio que restrinja o limite menos el ejercicio de la libertad de expresión:

79. En consecuencia, la Corte estima que la libertad e independencia de los periodistas es un bien que es preciso proteger y garantizar. Sin embargo, en los términos de la Convención, las restricciones autorizadas para la libertad de expresión deben ser las "necesarias para asegurar" la obtención de ciertos fines legitimos, es decir que no basta que la restricción sea útil (supra 46) para la obtención de ese fin, ésto es, que se pueda alcanzar a través de ella, sino que debe ser necesaria, es decir que no pueda alcanzarse razonablemente por otro medio menos restrictivo de un derecho protegido por la Convención.

La Corte concluye que el objetivo legítimo perseguido en términos de asegurar la libertad, responsabilidad y ética periodística, se pueden lograr por medios que sean menos restrictivos para la libertad de expresión que la colegiación obligatoria de los periodistas:

79. (...) En este sentido, la colegiación obligatoria de los periodistas no se ajusta a lo requerido por el artículo 13.2 de la Convención, porque es perfectamente concebible establecer un estatuto que proteja la libertad e independencia de todos aquellos que ejerzan el periodismo, sin necesidad de dejar ese ejercicio solamente a un grupo restringido de la comunidad.

81. De las anteriores consideraciones se desprende que no es compatible con la Convención una ley de colegiación de periodistas que impida el ejercicio del periodismo a quienes no sean miembros del colegio y limite el acceso a éste a los graduados en una determinada carrera universitaria. Una ley semejante contendría restricciones a la libertad de expresión no autorizadas por el artículo 13.2 de la Convención y sería, en consecuencia, violatoria tanto del derecho de toda persona a buscar y difundir informaciones e ideas por cualquier medio de su elección, como del derecho de la colectividad en general a recibir información sin trabas.

Así la Corte Interamericana determina por la unanimidad de sus magistrados que

"la colegiación obligatoria de periodistas, en cuanto impida el acceso de cualquier persona al uso pleno de los medios de comunicación social como vehículo para expresarse o para transmitir información, es incompatible con el artículo 13 de la Convención Americana sobre Derechos Humanos". 
3.3. La delimitación de la libertad de expresión incluye la probibición de censura previa y restricciones preventivas por parte de cualquier órgano o autoridad del Estado Parte, incluidas las resoluciones judiciales: el caso "Olmedo, Bustos y otros vs. Chile" o "La última Tentación de Cristo" y el caso "Ríos y otros vs. Venezuela".

La Corte Interamericana de Derechos Humanos ha utilizado la técnica de la delimitación de los derechos, determinando su contenido o haz de atributos que integran el derecho y sus fronteras o límites. El ejercicio de un derecho dentro de sus límites lo que equivale a ejercicio legítimo del derecho lo que nunca afecta otro derecho, ya que cada uno se ejerce dentro se su propio ámbito.

Cuando un acto o norma estatal afecta los atributos básicos o esenciales de un derecho, el tribunal simplemente aplica la técnica de la subsunción, determinando la violación del derecho humano por el acto o norma estatal que vulnera el derecho.

La libertad de expresión contenida en el artículo 13 de la CADH, que equivalente a la libertad de opinión y de información en el derecho constitucional chileno, tiene como uno de sus atributos básicos y esenciales el de su ejercicio sin censura previa.

Por ello, la Corte Interamericana en el caso La última tentación de Cristo, parte por delimitar el derecho a la libertad de pensamiento y expresión del artículo 13 de la $\mathrm{CADH}$ :

"64. En cuanto al contenido del derecho a la libertad de pensamiento y de expresión, quienes están bajo la protección de la Convención tienen no sólo el derecho y la libertad de expresar su propio pensamiento, sino también el derecho y la libertad de buscar, recibir $y$ difundir informaciones e ideas de toda indole. Es por ello que la libertad de expresión tiene una dimensión individual y una dimensión social, a saber:

ésta requiere, por un lado, que nadie sea arbitrariamente menoscabado o impedido de manifestar su propio pensamiento y representa, por tanto, un derecho de cada individuo; pero implica también, por otro lado, un derecho colectivo a recibir cualquier información y a conocer la expresión del pensamiento ajeno.

65. Sobre la primera dimensión del derecho consagrado en el artículo mencionado, la individual, la libertad de expresión no se agota en el reconocimiento teórico del derecho a hablar o escribir, sino que comprende además, inseparablemente, el derecho a utilizar cualquier medio apropiado para difundir el pensamiento y hacerlo llegar al mayor número de destinatarios. En este sentido, la expresión y la difusión del pensamiento y de la información son indivisibles, de modo que una restricción de las posibilidades de divulgación representa directamente, y en la misma medida, un límite al derecho de expresarse libremente.

66. Con respecto a la segunda dimensión del derecho consagrado en el artículo 13 de la Convención, la social, es menester señalar que la libertad de expresión es un medio para 
el intercambio de ideas e informaciones entre las personas; comprende su derecho a tratar de comunicar a otras sus puntos de vista, pero implica también el derecho de todas a conocer opiniones, relatos y noticias. Para el ciudadano común tiene tanta importancia el conocimiento de la opinión ajena o de la información de que disponen otros como el derecho a difundir la propia.

67. La Corte considera que ambas dimensiones poseen igual importancia y deben ser garantizadas en forma simultánea para dar efectividad total al derecho a la libertad de pensamiento y de expresión en los términos previstos por el artículo 13 de la Convención.

68. La libertad de expresión, como piedra angular de una sociedad democrática, es una condición esencial para que ésta esté suficientemente informada. "I2

Es conveniente tener presente que la Corte Interamericana reconoce la inspiración del artículo 13 de la $\mathrm{CADH}$ en el art. 19 del Pacto Internacional de Derechos Civiles y Políticos, señalando, sin embargo, también sus diferencias, en el párrafo 43 de la OC 5/85:

"En realidad, el artículo 13 de la Convención Americana, el que sirvió de modelo en parte al artículo 19 del Pacto, contiene una lista más reducida de restricciones que la Convención Europea y que el mismo Pacto, sólo sea porque éste no prohibe expresamente la censura previa"

A su vez, agrega en el párrafo 50 de la misma Opinión Consultiva que

"la comparación hecha entre el artículo 13 y las disposiciones relevantes de la Convención Europea (artículo 10) y el Pacto (artículo 19) demuestra claramente que las garantias de la libertad de expresión contenidas en la Convención Americana fueron diseñadas para ser más generosas y para reducir al minimum las restricciones a la libre circulación de las ideas".

La Corte Interamericana recuerda que esta libertad de expresión se ejerce en ausencia de toda censura previa, lo que preserva a las opiniones e informaciones del previo control o manipulación de la autoridad estatal sobre lo que se va a decir o a comunicar. La censura previa queda prohibida en todo caso y a ella se equipara toda medida preventiva, sin perjuicio de las responsabilidades ulteriores, con la única excepción contenida en el artículo 13 párrafo $4^{\circ}$ de la $\mathrm{CADH}$ :

"70. Es importante mencionar que el artículo 13.4 de la Convención establece una excepción a la censura previa, ya que la permite en el caso de los espectáculos públicos pero únicamente con el fin de regular el acceso a ellos, para la protección moral de la infancia

\footnotetext{
${ }^{12}$ Sentencia de la IIDH, Caso "La Última Tentación de Cristo" (Olmedo Bustos y otros) Vs. Chile de 5 de febrero de 2001, Serie C No 73, párrafos 64 a 68.
} 
y la adolescencia. En todos los demás casos, cualquier medida preventiva implica el menoscabo a la libertad de pensamiento y de expresión"13.

Cuando se vulnera la libertad de opinión o de información mediante censura o restricciones preventivas se viola el derecho de la persona afectada de emitir sus juicios de valor o ideas o de transmitir dichas ideas o determinados relatos de hechos o juicios de realidad a terceros, como asimismo se vulnera el derecho de todas las demás personas a recibir tales informaciones u opiniones.

La ausencia de censura previa implica ausencia de control preventivo de la autoridad gubernamental, administrativa, jurisdiccional, como asimismo, ausencia de normas jurídicas del Estado Parte que posibiliten dicho control.

Así lo explicita con claridad la Corte Interamericana, precisando:

"72. Esta Corte entiende que la responsabilidad internacional del Estado puede generarse por actos u omisiones de cualquier poder u órgano de éste, independientemente de su jerarquía, que violen la Convención Americana. Es decir, todo acto u omisión, imputable al Estado, en violación de las normas del Derecho Internacional de los Derechos Humanos, compromete la responsabilidad internacional del Estado. En el presente caso ésta se generó en virtud de que el artículo 19 número 12 de la Constitución establece la censura previa en la producción cinematográfica y, por lo tanto, determina los actos de los Poderes Ejecutivo, Legislativo y Judicial". ${ }^{14}$

La responsabilidad por las opiniones emitidas o la relación de los hechos o juicios emitidos a través de un medio de comunicación social no puede ser preventiva, lo que no implica que no exista responsabilidad o acciones posteriores a la publicación o difusión de las opiniones o informaciones, las que pueden ser civiles o penales, además del ejercicio del derecho de declaración, respuesta o rectificación. Así lo determina tanto la Convención Americana como nuestro texto constitucional en el artículo 19 No 12 , inciso $1^{\circ}$.

“... En esta materia toda medida preventiva significa, inevitablemente, el menoscabo de la libertad garantizada por Convención.

"39. El abuso de la libertad de expresión no puede ser objeto de medidas de control preventivo sino fundamento de responsabilidad para quién lo haya cometido. Aun en este caso, para que tal responsabilidad pueda establecerse válidamente, según la Convención, es preciso que se reúnan varios requisitos, a saber:

a) La existencia de causales de responsabilidad previamente establecidas.

${ }^{13}$ Sentencia Corte Interamericana, Caso La última tentación de Cristo, párrafo 70

${ }^{14}$ Sentencia Corte Interamericana, Caso La última tentación de Cristo, párrafo 72. 
b) La definición expresa y taxativa de esas causales por la ley.

c) La legitimidad de los fines perseguidos al establecerlos, $y$

d) Que esas causales de responsabilidad sean "necesarias para asegurar" los mencionados fines".

Todos estos requisitos debe ser atendidos para que se dé cumplimiento cabal al artículo 13.2. de la CADH.

Así la Corte Interamericana ha determinado que lo prohibido no es únicamente la censura previa, sino que, además, cualquier medida de carácter preventivo, de acuerdo con el artículo 13.2 de la $\mathrm{CADH}$, siendo posible sólo "responsabilidades ulteriores", expresión que se ocupó intencionalmente para reemplazar las expresiones "ciertas restricciones" que empleaba el Pacto Internacional de Derechos Civiles y Políticos en su artículo 19.3 que usó de inspiración el artículo 13.2 de la $\mathrm{CADH}$.

El régimen de libertad de expresión por el que opta deliberadamente la CADH es menos restrictivo que los establecidos en el Pacto Internacional de Derechos Civiles y Politicos (P.I.D.C. Y P) y la Convención Europea de Derechos Humanos (C.E.D.H). Como señaló el juez de la Corte Interamericana Pedro Nikken "... lo que es legitimo según el P.I.D.C. y P o según la C.E.D.H., puede ser ilegitimo en América, por apartarse de la Convención Americana (O.C.5/85, declaración $N^{\circ} 5$ )

Así, la Corte acepta como concepción de la libertad de expresión asegurada en la CADH la "prior restreint" doctrina o "regla de Blacktone", permitiendo sólo la excepción de la censura previa de espectáculos en orden a calificarlos para la protección moral de la infancia y adolescencia, aun cuando la expresión inglesa utilizada por la Convención es "prior censorship" (censura previa), siendo el resultado el mismo, ya que lo que se busca es admitir solamente y exclusivamente responsabilidades ulteriores, impidiendo toda acción preventiva que afecta el ejercicio de la libertad de expresión por la autoridad gubernativa, sea esta actividad desarrollada por la administración o la judicatura.

A su vez, la Corte Interamericana de Derechos Humanos en el caso "Ríos y otros vs. Venezuela" también se ha pronunciado sobre el artículo 13.3. de la Convención Americana sobre Derechos Humanos, precisando que:

"340. El artículo 13.3 de la Convención Americana dispone que "no se puede restringir el derecho de expresión por vías o medios indirectos, tales como el abuso de controles oficiales o particulares de papel para periódicos, de frecuencias radioeléctricas, o de enseres y aparatos usados en la difusión de información o por cualesquiera otros medios encaminados a impedir la comunicación y la circulación de ideas y opiniones". Una interpretación literal de esta norma permite considerar que protege en forma especifica la comunicación, 
difusión y circulación de ideas y opiniones, de modo que queda prohibido el empleo de "vías o medios indirectos" para restringirlas. La enunciación de medios restrictivos que hace el artículo 13.3 no es taxativa ni impide considerar "cualesquiera otros medios" o vías indirectas derivados de nuevas tecnologias. Además, el artículo 13.3 de la Convención impone al Estado obligaciones de garantía, aun en el ámbito de las relaciones entre particulares, pues no sólo abarca restricciones gubernamentales indirectas, sino también "controles... particulares" que produzcan el mismo resultado. Para que se configure una violación al artículo 13.3 de la Convención es necesario que la vía o el medio restrinjan efectivamente, aunque sea en forma indirecta, la comunicación y la circulación de ideas y opiniones". ${ }^{15}$

Cuando la Corte constata tras una adecuada delimitación de los derechos, que uno de ellos es afectado en su contenido esencial o se desnaturaliza, no hay nada que ponderar, sólo debe protegerse el derecho vulnerado por la acción del Estado a través de cualquiera de sus órganos que afecte el derecho a la libertad de expresión sin censura previa, sin perjuicio de las responsabilidades posteriores que puedan hacerse efectivas.

Es así que en el caso La última tentación de Cristo, la Corte Interamericana resuelve que:

"la probibición de la exhibición de la película "La última tentación de Cristo" constituyó, una censura previa impuesta en violación del artículo 13 de la Convención"

"En el presente caso, al mantener la censura cinematográfica en el ordenamiento jurídico chileno (artículo 19 No 12 de la Constitución Política y Decreto Ley No 679), el Estado está incumplido con el deber de adecuar su derecho interno a la Convención de modo de hacer efectivos los derechos consagrados en la misma, como lo establecen los artículos 2 y 1.1 de la Convención" ${ }^{17}$.

En virtud de dicha sentencia, la Corte Interamericana ordenó al Estado de Chile modificar el artículo 19 No 12 de la Constitución en su inciso final, lo que el Estado de Chile cumplió concretando la respectiva reforma constitucional mediante ley No 19.742 de 25 de agosto de 2001 y dictando la ley No 19.846 de 4 de enero de 2003, sobre Calificación de producción cinematográfica.

\footnotetext{
${ }^{15}$ Corte IDH. Caso Ríos y otros Vs. Venezuela. Excepciones Preliminares, Fondo, Reparaciones y Costas. Sentencia de 28 de enero de 2009. Serie C No. 194, párrafo 340.

${ }^{16}$ Sentencia de la Corte Interamericana de Derechos Humanos, caso "Bustos Olmedo y otros con Chile" o "La última tentación de Cristo", Excepciones Preliminares, Fondo, Reparaciones y Costas. 5 de febrero de 2001, párrafo 71 .

${ }^{17}$ Sentencia de la Corte Interamericana "La última tentación de Cristo", considerando 88.
} 


\subsection{La libertad de expresión vs. derecho a la honra y el uso del principio de proporcionalidad.}

\subsubsection{El caso Kimel con Argentina ${ }^{18}$.}

Así a manera ejemplar en el caso Kimel ${ }^{19}$, el periodista e historiador señor Kimel publica el libro "La masacre de San Patricio", ocurrida en Argentina en 1976, durante el régimen militar, en que fueron asesinados cinco religiosos de la orden palotina: En el libro Kimel realiza un análisis crítico de la intervención del juez de la causa y la paralización de la pesquisa. En 1991 el juez aludido promueve una querella criminal por el delito de calumnia en protección al derecho a su honra frente a la crítica recibida por su actuación en el caso, donde en definitiva, Kimel fue condenado a un año de prisión en suspenso y al pago de una indemnización de veinte mil pesos argentinos.

Kimel denunció al Estado argentino ante la Comisión Interamericana de Derechos Humanos por violación de éste de las obligaciones derivadas del artículo 13 de la $\mathrm{CADH}$, sobre aseguramiento y garantía de la libertad de expresión. El caso llegó a la Corte Interamericana, donde el Estado argentino se allanó a la demanda y reconoció su responsabilidad internacional, no obstante, la Corte decidió emitir sentencia, ya que ello constituiría una forma de reparación para el señor Kimel, especificando los hechos y elementos relevantes del caso, además de constituir una forma de evitar que se repitieran hechos análogos.

En el análisis del caso, la Corte Interamericana determina correctamente, que ambos derechos, libertad de expresión y derecho a la honra están asegurados por la $\mathrm{CADH}$, donde ninguno puede anular al otro, debiendo cada uno desarrollarse en la mayor medida posible, por tanto no puede emplearse en la materia la subsunción, sino la ponderación, a través de un escrutinio de proporcionalidad:

"54. Sin embargo, la libertad de expresión no es un derecho absoluto. El artículo 13.2 de la Convención, que prohibe la censura previa, también prevé la posibilidad de exigir responsabilidades ulteriores por el ejercicio abusivo de este derecho. Estas restricciones tienen carácter excepcional y no deben limitar, más allá de lo estrictamente necesario, el pleno ejercicio de la libertad de expresión y convertirse en un mecanismo directo o indirecto de censura previa.

${ }^{18}$ Corte IDH. Caso Kimel Vs. Argentina. Fondo, Reparaciones y Costas. Sentencia de 2 de mayo de 2008 Serie $\mathrm{C} \mathrm{N}^{\circ} 177$

${ }^{19} \mathrm{CIDH}$, Caso Kimel vs. Argentina, párrafo 36. 
55. Por su parte, el artículo 11 de la Convención establece que toda persona tiene derecho al respeto de su honra y al reconocimiento de su dignidad. Esto implica límites a las injerencias de los particulares y del Estado. Por ello, es legitimo que quien se considere afectado en su honor recurra a los medios judiciales que el Estado disponga para su protección.

56. La necesidad de proteger los derechos a la honra y a la reputación, así como otros derechos que pudieran verse afectados por un ejercicio abusivo de la libertad de expresión, requiere la debida observancia de los límites fijados a este respecto por la propia Convención. estos deben responder a un criterio de estricta proporcionalidad".

Para concretar el examen de proporcionalidad, la Corte Interamericana utiliza los tres subprincipios, adecuación o idoneidad, necesidad y proporcionalidad en sentido estricto. En efecto, la Corte Interamericana precisa:

"58. Teniendo en cuenta lo anterior, para resolver el caso concreto la Corte i) verificará si la tipificación de los delitos de injurias y calumnia afectó la legalidad estricta que es preciso observar al restringir la libertad de expresión por la vía penal; ii) estudiará si la protección de la reputación de los jueces sirve una finalidad legitima de acuerdo con la Convención y determinará, en su caso, la idoneidad de la sanción penal para lograr la finalidad perseguida; iii) evaluará la necesidad de tal medida, y iv) analizará la estricta proporcionalidad de la medida, esto es, si la sanción impuesta al señor Kimel garantizó en forma amplia el derecho a la reputación del funcionario público mencionado por el autor del libro, sin hacer nugatorio el derecho de éste a manifestar su opinión."

En el examen de adecuación o idoneidad, la Corte se interroga sobre si la restricción a la libertad de opinión concretada en la crítica ejercida por el señor Kimel producida por la aplicación de una sanción penal (calumnia) logra una adecuada promoción del derecho a la honra del juez concernido. En este examen la Corte interamericana se contenta con que el medio utilizado promueva de alguna manera dicha finalidad.

\section{“ii) Idoneidad y finalidad de la restricción}

“68. La Comisión alegó que la sanción impuesta al señor Kimel tuvo el propósito legitimo de proteger el honor de un funcionario público. Con todo, indicó que los funcionarios públicos deben ser más tolerantes a las críticas que los particulares y que el control democrático fomenta la transparencia de las actividades estatales, promueve la responsabilidad de los funcionarios públicos y que en un Estado de derecho no existe fundamento válido que permita sustraer de esta consideración a quienes trabajan en la administración de la justicia.

69. Los representantes indicaron que la Convención Americana no distingue al [P]oder [J] udicial respecto del resto de los poderes públicos, ni establece ninguna norma específica 
relacionada con la protección de la reputación de los jueces". Por el contrario, "en casos como el presente sólo rige la norma general que permite restringir la libertad de expresión para proteger los derechos o la reputación de los demás".

70. En este paso del análisis lo primero que se debe indagar es si la restricción constituye un medio idóneo o adecuado para contribuir a la obtención de una finalidad compatible con la Convención.

71. Como quedó establecido en el párrafo 55 supra, los jueces, al igual que cualquier otra persona, están amparados por la protección que les brinda el artículo 11 convencional que consagra el derecho a la honra. Por otra parte, el artículo 13.2.a) de la Convención establece que la "reputación de los demás" puede ser motivo para fijar responsabilidades ulteriores en el ejercicio de la libertad de expresión. En consecuencia, la protección de la honra y reputación de toda persona es un fin legitimo acorde con la Convención. Asimismo, el instrumento penal es idóneo porque sirve el fin de salvaguardar, a través de la conminación de pena, el bien jurídico que se quiere proteger, es decir, podría estar en capacidad de contribuir a la realización de dicho objetivo. Sin embargo, la Corte advierte que esto no significa que, en la especie que se analiza, la vía penal sea necesaria y proporcional, como se verá infra".

Lo cual lleva en escalera al examen del segundo subprincipio, el de necesidad donde la Corte Interamericana se interroga sobre si la restricción de la libertad de opinión (crítica) por la sanción penal que debió soportar el señor rimel era estrictamente necesaria o hay otras medidas alternativas que promuevan el mismo fin sin producir una afectación tan drástica de la libertad de expresión.

\section{“iii) Necesidad de la medida utilizada}

"72. La Comisión considera que el Estado tiene otras alternativas de protección de la privacidad y la reputación menos restrictivas que la aplicación de una sanción penal. En este sentido, [l] a protección a la reputación debe estar garantizada sólo a través de sanciones civiles, en los casos en que la persona ofendida sea un funcionario público o persona pública o particular que se haya involucrado voluntariamente en asuntos de interés público y a través de leyes que garanticen el derecho de rectificación o respuesta.

73. Los representantes señalaron que "cuando la conducta de una persona configura el ejercicio regular de un derecho [...], la mera existencia de una sanción-cualquiera que fuese-importa una violación a la Convención. Respecto de las sanciones penales alegaron que [a]l menos en el área de la crítica a los funcionarios públicos por sus actos funcionales, o a quienes se vinculan voluntariamente a asuntos de interés público, el recurso al derecho penal es contrario a la posibilidad de dar un debate amplio, ya que desalienta la participación de la ciudadanía, incluso, de los periodistas profesionales en la discusión de los asuntos públicos. En este sentido, el recurso penal genera un fuerte efecto inhibidor. Por otra parte, se manifestaron en contra de la existencia de sanciones civiles, toda vez que éstas también tienen un fuerte efecto inhibidor, en particular para las personas que 
desempeñan la función de periodista, por los relativamente exiguos salarios que se abonan en los medios de prensa; porque resulta virtualmente imposible afrontar las condenas que se establecen en los juicios de daños y perjuicios, sin que se genere un colapso en la economía personal del periodista o del ciudadano común, y porque, salvo acaso los grandes multimedios, ningún medio de comunicación ofrece garantias a sus trabajadores respecto de su capacidad de pago.

74. En el análisis de este tema, la Corte debe examinar las alternativas existentes para alcanzar el fin legitimo perseguido y precisar la mayor o menor lesividad de aquéllas.

75. El ejercicio de cada derecho fundamental tiene que hacerse con respeto y salvaguarda de los demás derechos fundamentales. En ese proceso de armonización le cabe un papel medular al Estado, buscando establecer las responsabilidades y sanciones que fueren necesarias para obtener tal propósito. Que se haga uso de la vía civil o penal dependerá de las consideraciones que abajo se mencionan.

76. La Corte ha señalado que el Derecho Penal es el medio más restrictivo y severo para establecer responsabilidades respecto de una conducta ilícita. La tipificación amplia de delitos de calumnia e injurias puede resultar contraria al principio de intervención minima $y$ de ultima ratio del derecho penal. En una sociedad democrática, el poder punitivo sólo se ejerce en la medida estrictamente necesaria para proteger los bienes jurídicos fundamentales de los ataques más graves que los dañen o pongan en peligro. Lo contrario conduciría al ejercicio abusivo del poder punitivo del Estado.

77. Tomando en cuenta las consideraciones formuladas hasta ahora sobre la protección debida de la libertad de expresión, la razonable conciliación de las exigencias de tutela de aquel derecho, por una parte, y de la honra, por la otra, y el principio de mínima intervención penal característico de una sociedad democrática, el empleo de la vía penal debe corresponder a la necesidad de tutelar bienes juridicos fundamentales frente a conductas que impliquen graves lesiones a dichos bienes, y guarden relación con la magnitud del daño inferido. La tipificación penal de una conducta debe ser clara y precisa, como lo ha determinado la jurisprudencia de este Tribunal en el examen del artículo 9 de la Convención Americana.

78. La Corte no estima contraria a la Convención cualquier medida penal a propósito de la expresión de informaciones u opiniones, pero esta posibilidad se debe analizar con especial cautela, ponderando al respecto la extrema gravedad de la conducta desplegada por el emisor de aquéllas, el dolo con que actuó, las características del daño injustamente causado y otros datos que pongan de manifiesto la absoluta necesidad de utilizar, en forma verdaderamente excepcional, medidas penales. En todo momento la carga de la prueba debe recaer en quien formula la acusación. En este orden de consideraciones, la Corte observa los movimientos en la jurisprudencia de otros Tribunales encaminados a promover, con racionalidad y equilibrio, la protección que merecen los derechos en aparente pugna, sin mellar las garantías que requiere la libre expresión como baluarte del régimen democrático.

79. De otro lado, en el marco de la libertad de información, el Tribunal considera que existe un deber del periodista de constatar en forma razonable, aunque no necesariamente 
exhaustiva, los hechos en que fundamenta sus opiniones. Es decir, resulta válido reclamar equidad y diligencia en la confrontación de las fuentes y la buisqueda de información. Esto implica el derecho de las personas a no recibir una versión manipulada de los hechos. En consecuencia, los periodistas tienen el deber de tomar alguna distancia crítica respecto a sus fuentes y contrastarlas con otros datos relevantes.

80. En lo que corresponde al presente caso, es notorio el abuso en el ejercicio del poder punitivo - como lo ha reconocido el propio Estado- tomando en cuenta los hechos imputados al señor Kimel, su repercusión sobre los bienes jurídicos del querellante y la naturaleza de la sanción-privación de libertad-aplicada al periodista.

Luego la Corte Interamericana termina el examen a través de la aplicación del principio de proporcionalidad en sentido estricto:

"83. En este último paso del análisis se considera si la restricción resulta estrictamente proporcional, de tal forma que el sacrificio inherente a aquélla no resulte exagerado o desmedido frente a las ventajas que se obtienen mediante tal limitación. La Corte ha hecho suyo este método al señalar que:

para que sean compatibles con la Convención las restricciones deben justificarse según objetivos colectivos que, por su importancia, preponderen claramente sobre la necesidad social del pleno goce del derecho que el artículo 13 de la Convención garantiza y no limiten más de lo estrictamente necesario el derecho proclamado en dicho artículo. Es decir, la restricción debe ser proporcional al interés que la justifica y ajustarse estrechamente al logro de ese legitimo objetivo, interfiriendo en la menor medida posible en el efectivo ejercicio del derecho a la libertad de expresión". ${ }^{20}$

Este examen no realiza un peso de las ventajas y desventajas en términos utilitaristas, sino que utiliza una ponderación orientada por reglas.

Para ello la Corte Interamericana precisa los elementos que debe considerar con anterioridad a la ponderación en sentido estricto, ellas son:

a) el grado de afectación de uno de los derechos en juego, determinando si la intensidad de dicha afectación es leve, media o grave;

b) la importancia de la satisfacción del derecho o bien contrario, y

c) si la satisfacción de uno de ellos justifica la restricción del otro

“iv) Estricta proporcionalidad de la medida

"81. La Comisión alegó que "la conducta del señor Kimel se encuadra dentro del ámbito razonable del ejercicio de su derecho a ejercer el periodismo de investigación, dado que se trataba de información de evidente interés para la opinión pública argentina, fundada

${ }^{20} \mathrm{CIDH}$, Caso Kimel vs. Argentina, Sentencia de 2 de mayo de 2008, Serie C No. 177, párrafo 36. 
en una investigación previa, que tenía por objeto aportar al debate y servir como medio fiscalizador de un funcionario público. En este sentido, indicó que en una sociedad que vivió una dictadura militar como la de Argentina desde 1976 hasta 1983 la libertad de pensamiento y expresión adquiere una importancia fundamental para la reconstrucción histórica del pasado y la formación de la opinión pública. En consecuencia, debe existir la posibilidad de que cualquier persona exprese sus opiniones de conformidad con el pensamiento propio, [...] de analizar con profundidad o sin ella la actuación de quienes detentaban cargos públicos durante esa época, entre ellos, del [P]oder [J] udicialy de emitir críticas incluso ofensivas y fuertes sobre ello. Agregó que el Juez mencionado por el señor Kimel deb[ía] tolerar las opiniones criticas que se re[firieran] al ejercicio de su función jurisdiccional.

82. Los representantes concordaron con la Comisión y alegaron que los hechos sobre los que informó el señor Kimel son de interés público, teniendo en cuenta que la investigación se refería a un caso paradigmático de la represión y que la investigación efectuada por el periodista es parte de [la] revisión que la sociedad argentina debe realizar y de la discusión acerca de las causas por las cuales el gobierno militar desplegó su accionar sin haber encontrado obstáculos en el [P]oder [J]udicial. Agregaron que el señor Kimel no utilizó lenguaje alguno que pudiera considerarse abusivo ni utilizó palabras desmedidas ni mucho menos ultrajantes; que se refirió al juez única y exclusivamente con motivo de su actuación funcional y no incursionó en ningún aspecto de su vida o de su personalidad que no guardara relación con su labor como funcionario público; que en los apartados del libro donde se manifiestan afirmaciones de hecho todo lo que sostuvo se ajusta a la realidad y que los párrafos que formaron parte del juicio penal contienen juicios de valor criticos sobre el poder judicial de aquella época, razón por la cual no son susceptibles de ser verdaderos o falsos, ni pueden justificar, por si mismos, una restricción a la libertad de expresión, en tanto se trata del derecho de toda persona de opinar libremente sobre asuntos de interés público y sobre la actuación funcional de un juez en un asunto de la mayor relevancia pública.

83. En este último paso del análisis se considera si la restricción resulta estrictamente proporcional, de tal forma que el sacrificio inherente a aquella no resulte exagerado o desmedido frente a las ventajas que se obtienen mediante tal limitación. La Corte ha hecho suyo este método al señalar que:

para que sean compatibles con la Convención las restricciones deben justificarse según objetivos colectivos que, por su importancia, preponderen claramente sobre la necesidad social del pleno goce del derecho que el articulo 13 de la Convención garantiza y no limiten más de lo estrictamente necesario el derecho proclamado en dicho artículo. Es decir, la restricción debe ser proporcional al interés que la justifica y ajustarse estrechamente al logro de ese legítimo objetivo, interfiriendo en la menor medida posible en el efectivo ejercicio del derecho a la libertad de expresión". 
La Corte Interamericana, en el caso Kimel, en su párrafo 84, utiliza el sistema de escala de satisfacción, donde la determinación de los valores de la escala se da en el contexto del sistema interamericano que garantiza el derecho a la libertad de expresión con mayores garantías que en el contexto europeo:

84. Para el caso que nos ocupa, la restricción tendría que lograr una importante satisfacción del derecho a la reputación sin hacer nugatorio el derecho a la libre crítica contra la actuación de los funcionarios públicos. Para efectuar esta ponderación se debe analizar i) el grado de afectación de uno de los bienes en juego, determinando si la intensidad de dicha afectación fue grave, intermedia o moderada; ii) la importancia de la satisfacción del bien contrario, y iii) si la satisfacción de éste justifica la restricción del otro. En algunos casos la balanza se inclinará hacia la libertad de expresión y en otros a la salvaguarda del derecho a la honra.

La Corte Interamericana determina que la restricción del derecho a la libertad de expresión de Kimel fue grave, al aplicarse una norma que establece una sanción penal que sólo debe utilizarse como ultima ratio, ya que es el medio más severo para establecer responsabilidades sobre la conducta de una persona, como señala en el párrafo 56. Asimismo la sanción penal tiene un carácter de estigma para la persona sancionada, como asimismo tiene un efecto disuasorio para el ejercicio de la libertad de expresión.

El peso abstracto del derecho a la libertad de expresión de Kimel es alto por la estrecha relación con el principio democrático, sobre la libertad de información de los ciudadanos, la crítica de las actuaciones de los servidores públicos y por tratarse de temas de relevancia pública (párrafo 62 a 64). En relación al derecho al honor u honra de los funcionarios públicos, está dado por la tolerancia al grado mas alto de crítica en su accionar en el cargo público al que voluntariamente accedió, estando mas expuesto a la crítica de sus actuaciones que son de relevancia pública, así la honra debe ser satisfecha en forma media, teniendo un peso abstracto bajo.

En el caso específico, una restricción grave a la libertad de expresión concretada bajo un análisis crítico de un periodista e historiador, a través de una investigación seria, sobre la tramitación de una causa por parte de un juez, el cual debe soportar y tolerar la crítica en el desarrollo de su función jurisdiccional por ser una función pública y la materia de relevancia pública, como es la investigación de una masacre durante una dictadura militar, donde la honra del juez tiene un peso medio y no se interfiere en forma grave, en dicho contexto la sanción penal a Kimel viola el principio de proporcionalidad como expresión de la prohibición de exceso (ÜbermaBverbot) :

"85. Respecto al grado de afectación de la libertad de expresión, la Corte considera que las consecuencias del proceso penal en sí mismo, la imposición de la sanción, la inscripción en 
el registro de antecedentes penales, el riesgo latente de posible pérdida de la libertad personal y el efecto estigmatizador de la condena penal impuesta al señor Kimel demuestran que las responsabilidades ulteriores establecidas en este caso fueron graves. Incluso la multa constituye, por si misma, una afectación grave de la libertad de expresión, dada su alta cuantía respecto a los ingresos del beneficiario.

86. Respecto al derecho a la honra, las expresiones concernientes a la idoneidad de una persona para el desempeño de un cargo público o a los actos realizados por funcionarios públicos en el desempeño de sus labores gozan de mayor protección, de manera tal que se propicie el debate democrático. La Corte ha señalado que en una sociedad democrática los funcionarios públicos están más expuestos al escrutinio y la crítica del público. Este diferente umbral de protección se explica porque se han expuesto voluntariamente a un escrutinio más exigente. Sus actividades salen del dominio de la esfera privada para insertarse en la esfera del debate público. Este umbral no se asienta en la calidad del sujeto, sino en el interés público de las actividades que realiza, como sucede cuando un juez investiga una masacre en el contexto de una dictadura militar, como ocurrió en el presente caso.

87. El control democrático a través de la opinión pública fomenta la transparencia de las actividades estatales y promueve la responsabilidad de los funcionarios sobre su gestión pública. De ahí la mayor tolerancia frente a afirmaciones y apreciaciones vertidas por los ciudadanos en ejercicio de dicho control democrático. Tales son las demandas del pluralismo propio de una sociedad democrática, que requiere la mayor circulación de informes y opiniones sobre asuntos de interés público.

88. En la arena del debate sobre temas de alto interés público, no sólo se protege la emisión de expresiones inofensivas o bien recibidas por la opinión pública, sino también la de aquellas que chocan, irritan o inquietan a los funcionarios públicos o a un sector cualquiera de la población. En una sociedad democrática, la prensa debe informar ampliamente sobre cuestiones de interés público, que afectan bienes sociales, y los funcionarios rendir cuentas de su actuación en el ejercicio de sus tareas públicas.

89. La crítica realizada por el señor Kimel estaba relacionada con temas de notorio interés público, se refería a un juez en relación con el desempeño de su cargo y se concretó en opiniones que no entrañaban la imputación de delitos. Tal como indicó la sentencia de primera instancia (supra párr. 43), el párrafo por el que fue procesado el señor Kimel involucraba una opinión y no el señalamiento de un hecho:

Kimel [...] se limita a abrir un interrogante [...]. En modo alguno, conforme doctrina y jurisprudencia imperantes en la materia, podría sostenerse válidamente que tales epitetos puedan constituir la atribución de una conducta criminal, en los términos requeridos por la figura típica y antijurídica [de calumnia]. El interrogante como tal, no puede implicar una imputación concreta, sino una mera valoración perfectamente subjetiva -y librada al subjetivismo también del lector-, por parte del autor, de una no menos subjetiva apreciación del valor probatorio de los elementos de juicio, incorporados al proceso, por parte del [querellante]. Trátase, en fin, de una crítica con opinión a la actuación de un Magistrado, frente a un proceso determinado. Pero la diferente apreciación de los hechos 
y circunstancias, en modo alguno, puede implicar la clara y rotunda imputación de un delito de acción pública.

90. Sobre el notorio interés público de los temas en torno a los cuales el señor Kimel emitió su opinión, cabe resaltar su testimonio en audiencia pública (supra párr. 9), no controvertido por el Estado:

La masacre de San Patricio ha[bia] sido considerado el hecho de sangre más importante que sufrió la Iglesia Católica a lo largo de varios siglos de existencia en la Argentina[.] El objetivo único y principal del libro evidentemente ha[bia] sido contar el asesinato de los religiosos palotinos, dar luz a aquello que habia permanecido oscuro e invisible a la sociedad, la tremenda historia del asesinato de cinco religiosos en su casa masacrados de la manera más horrible.

91. El señor Kimel emitió una opinión que no tenía relación con la vida personal del Juez querellante ni le imputaba una conducta ilícita, sino que se relacionaba con la causa judicial a su cargo.

92. La Corte observa que el señor Kimel realizó una reconstrucción de la investigación judicial de la masacre y, a partir de ello, emitió un juicio de valor critico sobre el desempeño del Poder Judicial durante la última dictadura militar en Argentina. En la audiencia pública del presente caso (supra párr. 9), el señor Kimel resaltó que el texto en el que se refiere al juez querellante era "un párrafo que debia estar en el libro porque contenía, a pesar de su brevedad, un dato significativo: cual habia sido la conducta de la justicia argentina durante aquellos trágicos años de la dictadura militar para investigar el asesinato de los sacerdotes”. El señor Kimel no utilizó un lenguaje desmedido y su opinión fue construida teniendo en cuenta los hechos verificados por el propio periodista.

93. Las opiniones vertidas por el señor Kimel no pueden considerarse ni verdaderas ni falsas. Como tal, la opinión no puede ser objeto de sanción, más aún, cuando se trata de un juicio de valor sobre un acto oficial de un funcionario público en el desempeño de su cargo. En principio, la verdad o falsedad se predica sólo respecto a hechos. De alli que no puede ser sometida a requisitos de veracidad la prueba respecto de juicios de valor.

94. Teniendo en cuenta lo anterior, la Corte concluye que la afectación a la libertad de expresión del señor Kimel fue manifiestamente desproporcionada, por excesiva, en relación con la alegada afectación del derecho a la honra en el presente caso.

\subsubsection{El Caso Usón Ramírez vs. Venezuela ${ }^{21}$}

En este caso, se analiza la legitimidad de la restricción del derecho a la libertad de expresión del general en retiro del ejército de Venezuela en virtud de una

${ }^{21}$ Corte IDH. Caso Usón Ramírez Vs. Venezuela. Excepción Preliminar, Fondo, Reparaciones y Costas. Sentencia de 20 de noviembre de 2009. Serie C No 207. 
vulneración de la honra o reputación de las Fuerzas Armadas de Venezuela, que se habría concretado por una entrevista a un medio de comunicación social.

La Corte aplicará al caso el principio de proporcionalidad en cada uno de sus subprincipios de idoneidad, necesidad y proporcionalidad en sentido estricto.

La Corte Interamericana comienza señalando que la $\mathrm{CADH}$ no protege la honra u honor de instituciones sino sólo de seres humanos, sin perjuicio de evaluar si esta reputación puede constituir un fin legítimo para restringir el derecho a la libertad de expresión:

"62. Como se señaló anteriormente (supra párr. 49), corresponde al Tribunal determinar si la protección de la reputación de las Fuerzas Armadas sirve una finalidad legitima que justifique una restricción de la libertad de expresión y, en su caso, si la sanción penal resulta idónea para lograr la finalidad perseguida.

63. Al respecto, la Corte toma nota que el derecho interno venezolano reconoce que las Fuerzas Armadas, como institución del Estado o persona jurídica, puede estar amparada por la protección del derecho a la honra o reputación. Asimismo, el artículo 13.2. a) de la Convención establece que la "reputación de los demás" puede ser motivo para fijar responsabilidades ulteriores en el ejercicio de la libertad de expresión. Si bien el sujeto del derecho al honor o a la reputación en este caso se trata de las Fuerzas Armadas, no de una persona fisica, y por ende no está protegido por la Convención, la protección del derecho al honor o a la reputación en si es considerada en la Convención como una de las finalidades legitimas para justificar una restricción al derecho a la libertad de expresión. En este sentido, el Tribunal reitera que al realizar un análisis sobre la legitimidad del fin señalado en el presente caso (la protección del derecho al honor o reputación de las Fuerzas Armadas), no se pretende determinar si efectivamente las Fuerzas Armadas tienen o no un "derecho" al honor o reputación, sino que se analiza si dicho fin sería legitimo para efectos de la restricción del derecho a la libertad de expresión que la Convención reconoce al señor Usón Ramírez".

La Corte Interamericana considera que la reputación de las Fuerzas Armadas puede ser considerado un fin legitimo a efectos de restringir el derecho a la libertad de expresión del General en retiro señor Uzón, para lo cual se atiende al criterio ya desarrollado por la Corte Europea de Derechos Humanos, que considera legítimo proteger la reputación de determinadas instituciones:

"64. Asimismo, el Tribunal observa que la Convención no establece que las únicas restricciones a derechos individuales que pueden ser legitimas son aquellas que pretenden proteger otros derechos individuales. Por el contrario, la Convención también contempla que sean legitimas aquellas restricciones que tengan como finalidad otros motivos no relacionados con el ejercicio de derechos individuales reconocidos en la Convención.

65. La Corte Europea de Derechos Humanos ha tenido oportunidad de pronunciarse sobre este tema y ha considerado que la protección del derecho a la reputación de compañias, no sólo de individuos, puede ser un fin legitimo para restringir el derecho a la libertad de 
expresion. En el caso Steel and Morris v. the United Kingdom, por ejemplo, el Tribunal Europeo realizó un análisis con relación a la necesidad de proteger el derecho a la libertad de expresión de los solicitantes y la necesidad de proteger la reputación y los derechos de [una compañia]. Igualmente, en el caso Kulis and Rózycki v. Poland el Tribunal Europeo señaló que la protección del derecho a la reputación de una compañia era un fin legitimo, en los términos del artículo 10.2 del Convenio Europeo.

66. Por tanto, el Tribunal considera que la finalidad en cuestión en el presente caso es legitima, en tanto pretende proteger un derecho que la normativa interna venezolana reconoce a las Fuerzas Armadas y que en términos generales se encuentra reconocido en la Convención Americana respecto de personas naturales. Sin embargo, resulta pertinente aclarar que la legitimidad del fin es sólo uno de los elementos en el presente análisis de proporcionalidady no necesariamente hace que la restricción en cuestión haya sido legal (lo cual ya fue analizado por el Tribunal supra, párrs. 50 a 58), por la vía idónea, necesaria o proporcional (lo cual el Tribunal analizará infra, párrs. 67 a 68)".

La Corte Interamericana, luego pasa al análisis del subprincipio de idoneidad o adecuación de medios, preguntándose si la norma penal que se aplicó al general (r) Uzón, es una medida idónea, considerando que si bien el instrumento penal en principio puede ser adecuado para proteger la honra o la reputación, es necesario analizar luego si ello es necesario o proporcional. En el caso concreto se considera que la norma penal es excesivamente vaga y no resulta idónea para garantizar el bien jurídico.

"67. En cuanto a la idoneidad de la vía penal para lograr la finalidad perseguida, la Corte ha advertido anteriormente, y vuelve a hacerlo en el presente caso, que si bien un instrumento penal puede ser idóneo para restringir el ejercicio abusivo de determinados derechos, siempre y cuando esto sirva al fin de salvaguardar el bien jurídico que se quiere proteger, lo anterior no significa que la utilización de la vía penal para la imposición de responsabilidades ulteriores al ejercicio de la libertad de expresión sea necesaria o proporcional en todos los casos (infra párrs. 69 a 88).

68. En el presente caso, la Corte ya declaró que la norma penal militar que determinó la responsabilidad ulterior del señor Usón Ramírez por el ejercicio de su libertad de expresión no es compatible con la Convención por ser excesivamente vaga y ambigua (supra párrs. 57 y 58). Consecuentemente, la Corte considera que en el caso que nos ocupa la vía penal no resultó ser idónea para salvaguardar el bien jurídico que se pretendía proteger".

La CIDH, en aplicación del subprincipio de necesidad, determina que deben analizarse las alternativas existentes para alcanzar el fin legítimo y aplicar aquella que menor daño cause al derecho que se ve afectado o restringido:

"72. En el análisis de este tema, como en otras ocasiones, la Corte debe examinar las alternativas existentes para alcanzar el fin legitimo perseguido y precisar la mayor o menor lesividad de aquéllas". 
La CIDH considera que el derecho penal es el medio más restrictivo, por lo cual debe ser aplicado como "última ratio", cuando es absolutamente indispensable para proteger los bienes jurídicos, de lo contrario implica un abuso de poder del Estado:

"73. La Corte ha señalado que el Derecho Penal es el medio más restrictivo y severo para establecer responsabilidades respecto de una conducta ilícita, particularmente cuando se imponen penas privativas de libertad. Por lo tanto, el uso de la vía penal debe responder al principio de intervención minima, en razón de la naturaleza del derecho penal como ultima ratio. Es decir, en una sociedad democrática el poder punitivo sólo se puede ejercer en la medida estrictamente necesaria para proteger los bienes jurídicos fundamentales de los ataques más graves que los dañen o pongan en peligro. Lo contrario conduciría al ejercicio abusivo del poder punitivo del Estado".

El uso del derecho penal para hacer efectivas restricciones ulteriores en materia de libertad de expresión debe ser analizada con cautela, debiendo utilizarse sólo en casos de extrema gravedad de la conducta del emisor de la expresión, debiendo analizarse además, recayendo la carga de la prueba en quién acusa, como señala la $\mathrm{CIDH}$ :

"74. (...) el dolo con que actuó, las caracteristicas del daño injustamente causado, las caracteristicas de la persona cuyo honor o reputación se pretende salvaguardar, el medio por el cual se pretendió causar el daño y otros datos que pongan de manifiesto la absoluta necesidad de utilizar, en forma verdaderamente excepcional, medidas penales. En todo momento la carga de la prueba debe recaer en quien formula la acusación".

La CIDH confirma su criterio expresado en casos anteriores, en que el tipo penal debe establecer con precisión las conductas que implican una lesión grave al derecho al honor u honra de la persona afectada:

"75. En este sentido, el Tribunal ha considerado en ocasiones anteriores que el ejercicio del poder punitivo del Estado ha resultado abusivo e innecesario para efectos de tutelar el derecho a la honra, cuando el tipo penal en cuestión no establece claramente qué conductas implican una grave lesión a dicho derecho. Ése fue el caso que ocurrió con el señor Usón Ramirez.".

Finalmente, la CIDH aplica el subprincipio de proporcionalidad en forma estricta, ponderando las ventajas de la limitación y el sacrificio del ejercicio del derecho afectado por la medida legislativa, debiendo ser la medida restrictiva proporcional y ajustarse estrictamente al fin legítimo, interfiriendo lo menos posible en el derecho afectado:

“79. En este paso del análisis se considera si la restricción resulta estrictamente proporcional, de tal forma que el sacrificio inherente a aquélla no resulte exagerado o desmedido frente a las ventajas que se obtienen mediante tal limitación. La Corte ha hecho suyo este método al señalar que: 
para que sean compatibles con la Convención las restricciones deben justificarse según objetivos colectivos que, por su importancia, preponderen claramente sobre la necesidad social del pleno goce del derecho que el artículo 13 de la Convención garantiza y no limiten más de lo estrictamente necesario el derecho proclamado en dicho artículo. Es decir, la restricción debe ser proporcional al interés que la justifica y ajustarse estrechamente al logro de ese legitimo objetivo, interfiriendo en la menor medida posible en el efectivo ejercicio del derecho a la libertad de expresión".

La Corte Interamericana aplica en la materia el criterio del peso de los bienes jurídicos o derechos en juego. Ello determina que la restricción de la libertad de expresión únicamente se justifica por una lesión grave del derecho a la reputación de las Fuerzas Armadas venezolanas, para lo cual la Corte determina el empleo de los siguientes criterios:

"80. (...) Para efectuar esta ponderación se debe analizar i) el grado de afectación de uno de los bienes en juego, determinando si la intensidad de dicha afectación fue grave, intermedia o moderada; ii) la importancia de la satisfacción del bien contrario, y iii) si la satisfacción de éste justifica la restricción del otro. En algunos casos la balanza se inclinará hacia la libertad de expresión y en otros a la salvaguarda del derecho a la honra y reputación".

La Corte Interamericana determina la gravedad de las consecuencias introducidas por el ordenamiento jurídico venezolano por la sanción penal como medida restrictiva de la libertad de expresión del general (r) Usón, explicitándolas:

81. Respecto al grado de afectación de la libertad de expresión, la Corte considera que las consecuencias del sometimiento a un proceso en el fuero militar (infra párrs. 107 a 116); el proceso penal en si mismo; la privación preventiva de libertad que se le impuso; la pena privativa de libertad de cinco años y seis meses a la que fue sentenciado; la inscripción en el registro de antecedentes penales; la pérdida de ingresos durante el tiempo encarcelado; la afectación en el goce del ejercicio de los derechos que se restringen en razón de la pena impuesta; el estar lejos de su familia y seres queridos; el riesgo latente de la posible pérdida de su libertad personal, y el efecto estigmatizador de la condena penal impuesta al señor Usón Ramírez demuestran que las responsabilidades ulteriores establecidas en este caso fueron verdaderamente graves.

A su vez, pondera la afectación del derecho a la reputación que habría sido afectado en el caso de las FF.AA. de Venezuela:

"82. Respecto a la importancia del derecho a la honra o reputación que el derecho interno reconoce a las Fuerzas Armadas, el Tribunal indicó en la presente Sentencia que no le corresponde determinar si las Fuerzas Armadas tienen o no un derecho al honor o a la reputación (supra párr. 45). No obstante lo anterior, de manera análoga, el Tribunal ha señalado anteriormente que es de gran importancia que se satisfaga el derecho al honor 
o a la reputación respecto de quien ha sido injuriado, particularmente si se trata de una imputación de un delito grave con respecto a un individuo. Sin embargo, la satisfacción de dicho bien no necesariamente justifica la restricción del derecho a la libertad de expresión en todo caso".

La CIDH recuerda que las expresiones vertidas respecto del ejercicio de funciones públicas gozan de mayor protección con el objeto de propiciar un debate público en la sociedad democrática, estando tales funciones sometidas al escrutinio y crítica pública, lo que se asienta en la relevancia pública de la actividad realizada, las demandas del pluralismo democrático y la circulación de opiniones e informaciones sobre asuntos de interés público:

"83. Al respecto, en el examen de proporcionalidad se debe tener en cuenta que las expresiones concernientes al ejercicio de funciones de las instituciones del Estado gozan de una mayor protección, de manera tal que se propicie el debate democrático en la sociedad. Ello es asi porque se asume que en una sociedad democrática las instituciones o entidades del Estado como tales están expuestas al escrutinio y la crítica del público, y sus actividades se insertan en la esfera del debate público. Este umbral no se asienta en la calidad del sujeto, sino en el interés público de las actividades que realiza. De ahi la mayor tolerancia frente a afirmaciones y apreciaciones vertidas por los ciudadanos en ejercicio de dicho control democrático. Tales son las demandas del pluralismo propio de una sociedad democrática, que requiere la mayor circulación de informes y opiniones sobre asuntos de interés público".

La CIDH precisa que en el caso concreto las opiniones vertidas por el señor Usón referidas al uso de lanzallamas en el Fuerte Mara de las FF.AA. venezolanas son sobre una materia de relevancia pública, siendo condenado sin tener en cuenta los requisitos que se desprenden de la CADH:

"84. En el presente caso, los señalamientos realizados por el señor Usón Ramírez se relacionaban con temas de notorio interés público. No obstante la existencia de un interés público sobre lo acontecido en el Fuerte Mara, dependencia de las Fuerzas Armadas del Estado, el señor Usón Ramírez fue juzgado y condenado sin que se tuvieran en cuenta los requisitos que se desprenden de la Convención Americana referentes a la mayor tolerancia que exigen aquellas afirmaciones y apreciaciones vertidas por los ciudadanos en ejercicio del control democrático.

85. Por otro lado, el Tribunal observa que en el proceso ante esta Corte el Estado enfatizó que el señor Usón Ramírez realizó varios otros pronunciamentos que no tenían que ver con el tema de interés público relativo al uso del lanzallamas, pero que podrían entenderse como injuria, ofensa o menosprecio hacia las Fuerzas Armadas. Sin embargo, como ya fue señalado (supra párrs. 37 y 38), los tribunales nacionales enmarcaron la condena del señor Usón Ramírez en los hechos relacionados con la supuesta imputación a las autoridades del Fuerte Mara de una "premeditación" en el uso de un lanzallamas. Los demás 
señalamientos del señor Usón Ramírez en el referido programa televisivo no forman parte de la parte motivada de la sentencia que lo condenó, según lo indicó la propia jurisdicción interna venezolana que determinó los hechos en base a los cuales juzgaría al señor Usón Ramírez, por lo que la Corte no se referirá al respecto".

La CIDH determina que el señor Usón fue sancionado en virtud de la emisión de una opinión crítica en una situación condicionada a la hipótesis de que los hechos hubieran ocurrido de una manera determinada, lo cual demuestra la ausencia de dolo y de voluntad de injuriar u ofender, por lo que la sanción penal es desproporcionada e ilegítima para castigar la emisión de opiniones sobre supuestos hechos ilícitos de interés público que involucran a las Fuerzas Armadas y sus miembros, lo que otorga una protección automática al honor o reputación de las Fuerzas Armadas que tiene un peso leve en el caso específico sin considerar el peso de la restricción grave del derecho a la libertad de expresión, lo que determina la falta de proporcionalidad en sentido estricto o la inadecuada ponderación de los derechos:

"86. Al respecto, la Corte observa que, por un lado, el tribunal nacional consideró que el señor Usón Ramírez habia emitido una opinión, no sólo una afirmación, y por otro lado, que dicha opinión a su vez afirmaba un hecho que no era cierto (supra párrs. 40 y 42). La Corte ha señalado anteriormente que las opiniones no pueden considerarse ni verdaderas ni falsas. Como tal, la opinión no puede ser objeto de sanción, más aún cuando dicha opinión esté condicionada a que se comprueben los hechos sobre los que se basa. En el presente caso, al condicionar su opinión, se evidencia que el señor Usón Ramírez no estaba declarando que se habia cometido un delito premeditado, sino que en su opinión se habría cometido tal delito en el caso que resultara cierta la hipótesis sobre el uso de un lanzallamas. Una opinión condicionada de tal manera no puede ser sometida a requisitos de veracidad. Además, lo anterior tiende a comprobar que el señor Usón Ramírez carecía del dolo especifico de injuriar, ofender o menospreciar, ya que, de haber tenido la voluntad de hacerlo, no hubiera condicionado su opinión de tal manera. Un razonamiento contrario, es decir, establecer sanciones desproporcionadas por realizar opiniones sobre un supuesto hecho ilícito de interés público que involucraba a instituciones militares y sus miembros, contemplando asi una protección mayor y automática al honor o reputación de éstos, sin consideración acerca de la mayor protección debida al ejercicio de la libertad de expresión en una sociedad democrática, es incompatible con el artículo 13 de la Convención Americana.

87. Por último, taly como lo ha señalado anteriormente, aun cuando la Corte Interamericana no puede, ni lo pretende, sustituir a la autoridad nacional en la individualización de las sanciones correspondientes a delitos previstos en el derecho interno, el Tribunal observa la falta de proporcionalidad que se advierte entre la respuesta del Estado a las expresiones vertidas por el señor Usón Ramirez y el bien jurídico supuestamente afectado - el honor o reputación de las Fuerzas Armadas. Al respecto, el Tribunal reitera que la racionalidad 
y proporcionalidad deben conducir la conducta del Estado en el desempeño de su poder punitivo, evitando asi tanto la lenidad característica de la impunidad como el exceso y abuso en la determinación de penas".

\section{Conclusiones}

La Corte Interamericana de Derechos Humanos al realizar el análisis de los casos en que se encuentran eventualmente vulnerados derechos humanos asegurados por la $\mathrm{CADH}$ utiliza tanto la técnica de delimitación de derechos cuando constata la afectación del ejercicio del haz de atributos básicos y esenciales de un derecho, como el postulado o principio de proporcionalidad cuando hay un conflicto real entre dos o mas derechos.

En efecto, en el "caso Olmedo Bustos y Otros vs. Chile", más conocido como La última tentación de Cristo", la Corte Interamericana determina que el Estado de Chile a través de las resoluciones de sus órganos jurisdiccionales violó el derecho a la libertad de expresión contenido en el artículo 13 de la $\mathrm{CADH}$, que determina que dicha libertad de expresión tiene como atributo básico y esencial, que ella se ejerce sin censura previa, incluyendo en el concepto de censura previa, el control desarrollado por cualquier órgano estatal, incluidos los tribunales de justicia, que impidan preventivamente el que los juicios de valor o de realidad expresados por una persona, a través de cualquier medio, puedan llegar a sus destinatarios, sin perjuicio de las responsabilidades posteriores. Esta perspectiva de prohibición de censura previa tiene una excepción, la que contempla el artículo 13.4 de la Convención, que permite en el caso de los espectáculos públicos pero únicamente con el fin de regular el acceso a ellos, para la protección moral de la infancia y la adolescencia. En todos los demás casos, cualquier medida preventiva implica el menoscabo a la libertad de pensamiento y de expresión. En tales casos, no hay conflictos de derechos, sino sólo vulneración del ejercicio legítimo del contenido esencial del derecho a la libertad de expresión. Asimismo, la Corte Interamericana determina los requisitos que posibilitan la determinación de responsabilidades ulteriores, para lo cual se requiere: A) La existencia de causales de responsabilidad previamente establecidas.B) La definición expresa y taxativa de esas causales por la ley. C) La legitimidad de los fines perseguidos al establecerlos, y d) Que esas causales de responsabilidad sean "necesarias para asegurar" los mencionados "fines".

Por otra parte, la Corte Interamericana de Derechos Humanos, utiliza el principio o postulado de proporcionalidad, el cual cumple una función argumentativa en la interpretación de los derechos o bienes jurídicos, apoyado en argumentos objetivos que dotan de razones justificadoras a la resolución judicial, en el caso que nos interesa, la Corte Interamericana utiliza el postulado o principio de proporcionalidad para resolver las tensiones que se producen entre los derechos a la 
libertad de pensamiento y expresión y el derecho a la honra, ambos asegurados por la $\mathrm{CADH}$, buscando su adecuada concordancia práctica o perspectiva coexistencial, unitaria y sistemática, superando una concepción conflictivista y jerarquizadora de los derechos. En tal perspectiva, se encuentran los casos contenciosos "Kimel con Argentina" y "Usón Ramírez vs. Venezuela" ya analizados.

En el caso "Kimel con Argentina" la Corte Interamericana establece como premisa básica que el ejercicio de todo derecho fundamental debe concretarse en el respeto de los demás derechos que integran el sistema, existiendo el deber de armonizarlos y producir una concordancia práctica entre ellos. A su vez, la constatación de la vulneración de un derecho fundamental puede llevar aparejada una determinada responsabilidad y sanción necesaria y proporcionada para proteger un bien o fin legítimo, la restricción que implica la sanción civil o penal debe ajustarse estrechamente al logro de ese legítimo objetivo, interfiriendo en la menor medida posible en el efectivo ejercicio del derecho a la libertad de expresión.

La Corte Interamericana determina que forma parte de la libertad de expresión contenida en el artículo 13 de la $\mathrm{CADH}$, el derecho de toda persona de opinar libremente sobre asuntos de interés público y sobre la actuación funcional de un juez en un asunto de relevancia pública, opiniones que no entrañaban la imputación de delitos. La Corte Interamericana precisa que un juez debe soportar y tolerar la crítica en el desarrollo de su función jurisdiccional por ser una función pública y la materia sobre la materia que versa la crítica es de relevancia pública, como es la investigación de una masacre durante una dictadura militar, donde la honra del juez tiene un peso medio.

La Corte Interamericana precisa que, en una sociedad democrática, los funcionarios públicos están más expuestos al escrutinio y la crítica del público. Este diferente umbral de protección se explica porque se han expuesto voluntariamente a un escrutinio más exigente. Sus actividades salen del dominio de la esfera privada para insertarse en la esfera del debate público. Este umbral no se asienta en la calidad del sujeto, sino en el interés público de las actividades que realiza, como sucede cuando un juez investiga una masacre en el contexto de una dictadura militar, como ocurrió en el presente caso.

La Corte Interamericana determina que el señor Kimel no utilizó un lenguaje desmedido y su opinión fue construida teniendo en cuenta los hechos verificados por el propio periodista. Las opiniones vertidas por el periodista no pueden considerarse ni verdaderas ni falsas. Como tal, la opinión no puede ser objeto de sanción, más aún cuando se trata de un juicio de valor sobre un acto oficial de un funcionario público en el desempeño de su cargo. En principio, la verdad o falsedad se predica sólo respecto a hechos. De allí que no puede ser sometida a requisitos de veracidad la prueba respecto de juicios de valor. 
La Corte Interamericana determina en dicho caso que la aplicación de una sanción penal por los tribunales argentinos al señor Kimel por expresar opiniones críticas en el marco de una investigación judicial respecto de la actuación del magistrado viola el principio de proporcionalidad como expresión de la prohibición de exceso y restringe gravemente el derecho de libertad de expresión.

En el caso "Usón Ramírez vs. Venezuela”, la Corte determina que la $\mathrm{CADH}$ no protege la honra u honor de instituciones sino sólo de seres humanos, sin perjuicio de aceptar que la reputación de una institución puede constituir un fin legítimo para restringir el derecho a la libertad de expresión.

La Corte Interamericana aplica en la materia el criterio del peso de los bienes jurídicos o derechos en juego. Ello determina que la restricción de la libertad de expresión únicamente se justifica por una lesión grave de la honra de personas o reputación de instituciones.

Para concretar dicha ponderación analiza: A) el grado de afectación de uno de los bienes en juego, determinando si la intensidad de dicha afectación fue grave, intermedia o moderada; B) la importancia de la satisfacción del bien contrario, y C) si la satisfacción de éste justifica la restricción del otro. En algunos casos la balanza se inclinará hacia la libertad de expresión y en otros a la salvaguarda del derecho a la honra y reputación."

La Corte Interamericana determina que los antecedentes del caso demuestran que las responsabilidades ulteriores establecidas en este caso para el general Usón fueron verdaderamente graves, agregando que en el examen de proporcionalidad se debe tener en cuenta que las expresiones concernientes al ejercicio de funciones de las instituciones del Estado gozan de una mayor protección, de manera tal que se propicie el debate democrático en la sociedad.

La Corte Interamericana determina que la sanción penal es desproporcionada e ilegítima para castigar la emisión de opiniones sobre supuestos hechos ilícitos de interés público que involucran a las Fuerzas Armadas y sus miembros, lo que otorga una protección automática al honor o reputación de las Fuerzas Armadas que tiene un peso leve en el caso específico sin considerar el peso de la restricción grave del derecho a la libertad de expresión, lo que determina la falta de proporcionalidad en sentido estricto o la inadecuada ponderación de los derechos

La Corte Interamericana de Derechos Humanos fija así estándares jurisprudenciales basados en el principio de proporcionalidad que deben ser tenidos en consideración por las jurisdicciones nacionales, especialmente en consideración del control de convencionalidad que deben realizar respecto del derecho interno aplicable a los casos específicos. 


\section{BibLIOGRAFíA}

AleXY, R. (1993): Teoría de los derechos fundamentales. Traducción de Ernesto Garzón, Centro de Estudios Constitucionales.

Alexy, R. (2002): "Epílogo a la Teoría de los Derechos Fundamentales", Revista Española de Derecho Constitucional $N^{\circ} 66$, Madrid, Ed. Centro de Estudios Constitucionales.

Bernal Pulido, Carlos (2003): El principio de proporcionalidad y los derechos fundamentales. Madrid, Centro de Estudios Políticos y Constitucionales.

Bernal Pulido, Carlos (2005): El derecho de los derechos (Bogotá. Ed. Universidad Externado de Colombia).

Bonavides, Pablo (1994): Curso de Direito Constitucional, Quinta edición (Sao Paulo, Malheiros).

Brage Camazano, Joaquín (2004): Los limites a los derechos fundamentales (Madrid, Ed. Dykinson S.L).

CARBOnell, Miguel (Coord.) (2010): El principio de proporcionalidad en la interpretación jurídica (Santiago de Chile, Ed. CECOCH Instituto de Investigaciones Jurídicas, UNAM).

CiAnCIARDO, J. (2004): El principio de razonabilidad: del debido proceso sustantivo al moderno juicio de proporcionalidad (Buenos Aires, Abaco de Rodolfo Depalma).

ClÉRICO, Laura (2009): El examen de proporcionalidad en el derecho constitucional. Buenos Aires, Facultad de Derecho, Universidad de Buenos Aires y EUDEBA, Clérico, Laura (2010): La proporcionalidad y la Corte Interamericana de derechos Humanos. Hacia la reconstrucción de un modelo integrado de proporcionalidad o el ritmo que impone la tragedia de los casos. Trabajo inédito presentado en el Simposio Humboldt en Universidad de Buenos Aires, "Internacionalización del derecho constitucional, constitucionalización del derecho internacional", Facultad de Derecho, Universidad de Buenos Aires, 3 al 6 de octubre de 2010.

FASSBENDER, Bardo (1998): "El principio de proporcionalidad en la jurisprudencia del Tribunal Europeo de Derechos Humanos". Cuadernos de Derecho Público No 5. Ministerio de Administraciones Públicas: Instituto Nacional de Administración Pública, Madrid, pp. 51-74.

Lopera Mesa, G. (2006): Principio de proporcionalidad y control de constitucionalidad de las leyes penales (Madrid. Centro de Estudios Políticos y Constitucionales), pp. 661. 
SCHWAVE, Jürgen (2003). Cincuenta años de jurisprudencia del Tribunal Constitucional Federal Alemán (Montevideo. Ed. Jurídico Gustavo Ibáñez y KAS).

Opinión Consultiva y Sentencias de la Corte Interamericana de Derechos Humanos.

CIDH. La Colegiación Obligatoria de Periodistas (Arts. 13 y 29 Convención Americana sobre Derechos Humanos). Opinión Consultiva OC-5/85 del 13 de noviembre de 1985. Serie A No 5.

CIDH, "La última tentación de Cristo", Sentencia 5 de febrero de 2001. Serie C No 73.

CIDH, Caso Kimel vs. Argentina, Sentencia de 2 de mayo de 2008, Serie C No 177.

Corte IDH. Caso Ríos y otros Vs. Venezuela. Sentencia de 28 de enero de 2009. Serie C No 194.

Corte IDH. Caso Usón Ramírez Vs. Venezuela. Sentencia de 20 de noviembre de 2009. Serie C No 207. 